\section{Synthesis and Biological Activity of Peptides Related to Bradykinin}

Bradylkinin has been obtained from plasma globulins by the action of various enzymes ${ }^{1}$. The amino acid composition $^{2,3}$, the structure ${ }^{4}$, and the biological properties ${ }^{3}$ of the pure product have recently been studied by $E_{L}-$ LIOTT, HORTON, and LEwIS. We wish to report on the synthesis and the biological activity of several peptides related to bradykinin (Table).

\section{Structure of peptides $\mathrm{A}-\mathrm{F}$}

H-L-Arg-I.-Pro-L-Pro-Gly-L-Phe-L-Ser-L-Pro-L-Phe-L-Arg-OH A H-L-Arg-L-Pro-Gly-L-Phe-L-Ser-L-Pro-L-Phe-L-Arg-OH . . B H-L-Arg-L-Pro-L-Pro-Gly-L-Phe-L Ser-L-Phe-L-Arg-OH . . C H-L-Arg-L-Pro-L-Pro-L-Phe-Gly-L-Ser-L-Phe-L-Arg-OH . . D H-L-Arg-L-Pro-Gly-L-Pro-L-Phe-L-Ser-L-Phe-L-Arg-OH . . E H-L-Arg-L-Pro-Gly-L-Phe-L-Ser-L-Phe-L-Arg-OH . . . . F

$\mathrm{CBO}$-(nitro)Arg-Pro-OH (I) was condensed with $\mathrm{H}$-ProGly-NHNH-CTO (II) ${ }^{s}$ by dicyclohexylcarbodiimid. By selective splitting of the CTO group and treatment with nitrous acid, CBO-(nitro)Arg-Pro-Pro-Gly- $\mathrm{N}_{3}$ (III) was obtained. Condensation of CBO-Phe-Ser- $\mathrm{N}_{3}$ (IV) with $\mathrm{H}$ Pro-Phe-(nitro)Arg-OBzN (V) ${ }^{5}$ and selective splitting of the $\mathrm{CBO}$ group yielded H-Phe-Ser-Pro-Phe-(nitro)Arg$\mathrm{OBzN}$ (VI), which was condensed with III to CBO-(nitro) Arg-Pro-Pro-Gly-Phe-Ser-Pro-Phe-(nitro)Arg-OBzN(VII). Catalytic hydrogenation of VII yielded A. By using CBO(nitro) Arg-Pro-Gly-OH (VIII) (from I and H-Gly-OH) instead of III, B was obtained. By condensing IV with H-Phe-(nitro) Arg-OBzN (IX) and splitting the CBO group, H-Phe-Ser-Phe-(nitro)Arg-OBzN (X) was obtained; by condensation with III, followed by catalytic hydrogenation, this led to C. Condensation of IX with CBO-Gly-Ser$\mathrm{N}_{3}$ followed by splitting of the CBO group and condensation with CBO-Pro-Phe-OH gave a hexapeptide, which, after splitting of the $\mathrm{CBO}$ group, was condensed with I. Catalytic hydrogenation of the protected octapeptide gave D. Condensation of I with H-Gly-Pro-OH followed by condensation with $X$ and catalytic hydrogenation gave $E$. Condensation of VIII with $\mathrm{X}$, followed by catalytic hydrogenation gave $F$. All the intermediary and final products were obtained in an analytically pure state.

The biological activity of the peptides $A-F$ was first determined on the isolated guinea pig ileum. The peptides $C, D, E$, and $F$ were without effect in doses up to $2.5 \mu \mathrm{g} / \mathrm{ml}$, whereas $A$ and $B$ produced a slow contraction in concentrations as small as $1 \mathrm{ng} / \mathrm{ml}$ and $100 \mathrm{ng} / \mathrm{ml}$ respectively. Boiling with concentrated $\mathrm{HCl}$ or incubation with guinea pig serum destroyed the activity, whereas pretreatment of the muscle. with atropine and/or an antihistamine agent (Thenalidine) only slightly interfered with the activity.

The nonapeptide A was further investigated using tests known to be sensitive for bradykinin 1,3,6. The following results were obtained: On the rabbit duodenum, the concentration required to elicit contraction was $1 \mathrm{ng} / \mathrm{ml}$. To produce a depressor response in anesthetized rabbits, rats, guinea pigs, cats, and dogs, the doses ranged from 200 to $400 \mathrm{ng} / \mathrm{kg}$. Bronchoconstriction in the guinea pig occurred with $200 \mathrm{ng} / \mathrm{kg}$. An effect on capillary permeability to a circulating dye (Evan's Blue) in guinea pigs after intradermal injection was observed with $1 \mathrm{ng}$.

On a molar basis, the nonapeptide $A$ was more active than histamine (ileum, bronchial muscle, and capillary permeability of the guinea pig) and acetylcholine (duodenum of the rabbit, blood pressure of the rabbit and dog).
The nonapeptide $A$ is therefore one of the most active biological substances exerting a bradykinin-like effect. Further work will demonstrate if it is identical with or closely similar to pure bradykinin.

\section{R. A. Boissonnas, St. Guttmann, \\ P.-A. Jaguenoud, H. Konzett, and E. Stürmer}

Pharmazeutisch-chemisches und pharmakologisches Laboratorium der Sandoz AG., Basel, June 2, 1960.

\section{Zusammenfassung}

Die Synthese von 6 Polypeptiden aus den im Bradykinin vorkommenden Aminosäuren wird beschrieben. Das Nonapeptid H-L-Arg-L-Pro-L-Pro-Gly-L-Phe-L-Ser-L-ProL-Phe-L-Arg-OH zeigte hohe Bradykinin-ähnliche Wirksamkeit in verschiedenen biologischen Testen.

1 M. Rocha e Silva, Biochemistry and Pharmacology of Bradykinin, in M. Schachter, Polypeptides which Affect Smooth Muscles and Blood Vessels (Pergamon Press, Oxford-London-New York-Paris $1969)$.

2 D. F. Elliot, G. P. LEwIs, and E. W. Horron, Biochem. J. $74,15 \mathrm{P}(1960)$.

${ }^{3}$ D.F. Elllot, E. W. Horton, and G. P. Lewts, J. Physiol. $150,6 \mathrm{P}(1960)$.

4 D. F. Exhote, paper read to the Biochemical Society (London) on April 8, 1960. We thank Dr. Elturotr for kindly giving us some of his results before communication.

5 $\mathrm{CBO}=$ carbobenzoxy; $\mathrm{CTO}=$ carbo-ter-butoxy; OB2N $=p$ nitrobenzoxy.

6 H. O. J. Collier, J.A. Holgate, M. Schachter, and P.G. Shorley, J. Physiol. 149, $54 \mathrm{P}(1959)$.

\section{Muscle Atrophy Following Section of the Spinal Cord in the Rat}

FISCHER ${ }^{1}$, SolandT and MAGLADERY ${ }^{2}$ observed that the course of muscle atrophy, following transection of the spinal cord, is biphasic. During the first 10-14 days following complete transection of the cord and unilateral denervation, the gastrocnemius-soleus muscle was found to atrophy on the 'plegic' side (i.e. after lesion of the upper motor neuron) at a similar rate as on the side of denervation (i.e. after lower motor lesion). Later, however, the plegic muscles gained in weight, so that 56 days after the operation their weight returned almost to initial values. In neither of these reports, however, have changes in total body weight occurring in the course of the experiment been taken into account. It is plausible to assume that if there are any changes in body weight, they might influence the interpretation of these results.

For this reason experiments were performed in an identical manner as those of the above authors. The spinal cord was sectioned at $\mathrm{Th}_{\mathrm{f}}$ in female rats $(190-205 \mathrm{~g}$ body weight) and at the same time the sciatic nerve was cut and its central stump ligated to prevent regeneration of nerve axons. The soleus and gastrocnemius muscles were then excised in different groups of animals 7, 14, 28 and, 56 days after the operation. The body weight of all animals was carefully registered. As can be seen from the Figure,

1 E. Fischer, Proc. Soc, exp. Biol. Med. 47, 277 (1941). $(19+2)$.
E. Fischer, Proc. Soc, exp. Biol. Med. $47,277(1941)$
D. Y. Solandt and J. W. Magladery, J. Neurophysiol. 5,373 